\title{
The Encumbrance of Institutional Investor and Board of Directors in Reducing Risk of Default for Conventional Bonds and Sukuk in Malaysia
}

\author{
(Hubungkait Pelabur Institusi dan Lembaga Pengarah Syarikat terhadap Pengurangan Risiko Tidak-bayar \\ untuk Bon dan Sukuk di Malaysia)
}

\author{
Noriza Mohd Saad \\ (College of Business Management \& Accounting, Universiti Tenaga Nasional) \\ Mohd Nizal Haniff \\ Norli Ali \\ (Faculty of Accountancy, Universiti Teknologi MARA)
}

\section{ABSTRACT}

Sukuk yields mimic those of conventional bonds due to having similar features. Sukuk are shariah-compliant securities that offer different structures to those of conventional bonds. Therefore, it is believed that the spreading of yields should also be different. The presence of key institutional investors/owners and certain Board of Directors (BOD) characteristics as highlighted by the Malaysian Code on Corporate Governance (MCCG) may influence the yield to maturity (YTM) of conventional bonds and sukuk. Thus, the main objective of this study is to investigate the relationship between these two yield spreads instruments with corporate governance mechanisms. The data is obtained from firm issuers' annual reports, the Bondinfo Hub of the Malaysian Central Bank, the Rating Agency Malaysia (RAM), the Malaysian Department of Statistics and Bloomberg databases for the period beginning 2000 to 2014 for 256 and 405 tranches of long-term and medium-term issuances of conventional bonds and sukuk respectively. The most significant findings show that the presence of top-six and other institutional ownerships as corporate governance mechanism proxy insignificantly and significantly reduce yield spreads within the firm revealed by Ordinary Least Square (OLS) and random effects models in long-term and medium-term issuances.

Keywords: Institutional ownership; board of directors; yield spreads; robust; default risk

ABSTRAK

Sukuk adalah sekuriti patuh-shariah yang mempunyai struktur berbeza berbanding struktur bon konvensional tetapi mempunyai ciri-ciri yang hampir serupa. Sehubungan itu, pembahagian julat hasil sepatutnya tidak sama. Kehadiran pelabur/pemilik institusi utama serta ciri-ciri Lembaga Pengarah (LP) yang tertentu yang ditekankan oleh Kod Tadbir Urus Korporat Malaysia (MCCG) mungkin mempengaruhi hasil hingga tempoh matang (YTM) bagi bon konvensional dan sukuk. Oleh itu, tujuan utama kajian ini adalah untuk menyelidik hubungan di antara julat hasil kedua-dua instrumen ini dengan mekanisme tadbir urus korporat. Data kajian diambil dari laporan tahunan syarikat penerbit, Bondinfo Hub Bank Negara Malaysia, Rating Agency Malaysia (RAM), Jabatan Perangkaan Malaysia dan Bloomberg bermula dari tahun 2000 sehingga 2014 ke atas penerbitan bon-bon konvensional dan sukuk jangka-panjang dan jangka-sederhana, masing-masing sebanyak 256 dan 405 tranch. Penemuan utama menunjukkan bahawa kehadiran pemilikan enam teratas dan lain-lain institusi sebagai proksi mekanisma tadbir urus korporat masing-masing mengurangkan julat hasil secara tidak signifikan dan signifikan seperti yang diperolehi dari model 'ordinary least squares' dan 'random effects' bagi penerbitan jangka-panjang dan jangka-sederhana.

Kata kunci: Pelabur institusi; lembaga pengarah; julat hasil; dinamik; risiko tidak-bayar

\section{INTRODUCTION}

Firms and even governments are sometimes faced with the problem of scarcity of funds to finance profitable investments and promote economic development. The massive amount of funding required for these purposes is unlikely to be serviced by commercial banks. One way to rise funding is from financial institutions and public through the issuance of debt instruments. The instruments used are the sale of bonds, shares, and other forms of debt and equity, both in conventional and Islamic systems. The source of funding for such projects is from the public via the capital market which is a platform for trading of these financial instruments. The increasing demand from the public sector for innovative forms of finance continues to fuel the development of Malaysia's debt securities market. Growth has also been spurred by the increasing presence of institutional investors, such as pension funds, unit trust funds and insurance companies.

Another notable achievement is the successful promotion of the Islamic capital market in the form of sukuk securities which comply with shariah principles, have played a major role in Malaysia's capital market development, contributing to the significant growth of 
the country's Islamic financial system. This market has enjoyed enormous growth whereby USD1.814 trillion of assets are being managed in a shariah-compliant manner as of the year 2014 with the potential to increase to USD3.247 trillion by the year 2020. Out of this value, there was USD295 billion of sukuk outstanding as of the end of 2014 (Thomson Reuters 2015). Also, the Malaysian corporate bond market represented $37 \%$ of the country's Gross Domestic Product (GDP) in 2004 and by this measure; it becomes one of the largest in the world (IMF 2005).

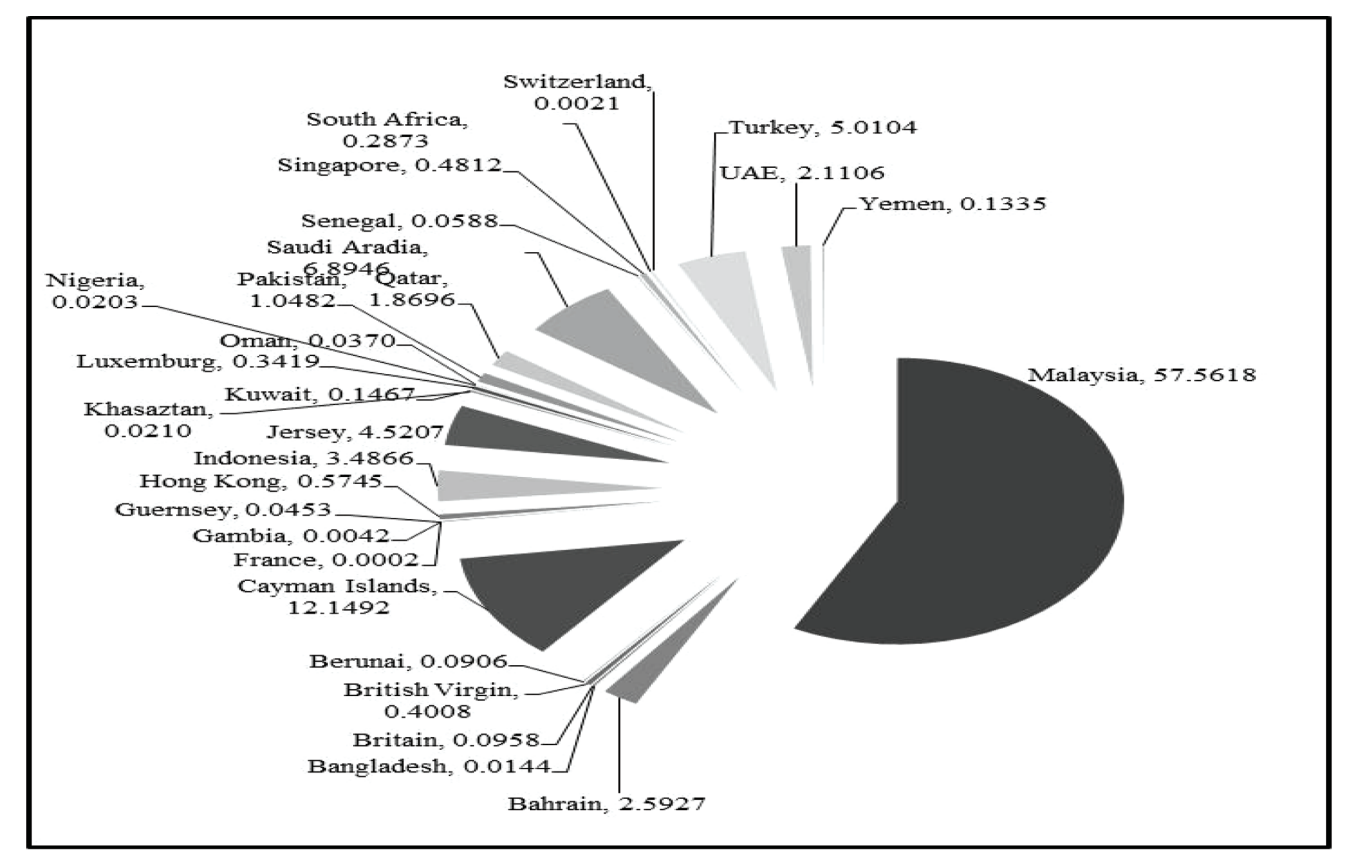

Source: The Author's calculation from data on the value of country issuances obtained from Bloomberg.

FIGURE 1. The percentage of sukuk size issuances (in MYR) by Country, 2000-2014

In 2014, Malaysia had a total sukuk issuance for MYR657 billion and leads the market with $57.6 \%$ of total sukuk issued from among 28 countries (Bloomberg 2015). Even though the sukuk market is relatively new as opposed to the bond market for public listed firms with the first issued in 1990 by Shell MDS through issuing $\mathrm{Al}$ bai Bithaman Ajil (BBA) sukuk worth MYR125 million in Malaysia (IIFM 2012), it has recorded significant growth from year to year. This growth has raised the question whether sukuk can play the role of an alternative source of financing and investment which might replace or substitute conventional bonds (Said \& Grassa 2013; Naifar 2016). The decision for the choice of debt financing needs to be analysed further on the yield to maturity (YTM) spreads (the difference in yield between the issuance tranche with Malaysian Treasury Bills for the same maturity of year period) for lesser risk in terms of default risk to the issuer.

\section{ISSUES AND MOTIVATION OF THE STUDY}

Capital market trading is unlike the money market whereby short-term and medium-term securities are transacted but it is for medium-term and long-term debt securities (ISRA \& SC 2015; Said W. Suhaimi \& Haris 2013). Particularly, sukuk can be either medium to long-term issuances and can have either fixed or variable rates of return and tradable or non-tradable (Khan \& Ahmed 2001; Tariq \& Dar 2007). Features of sukuk are identical and might be replication of conventional bonds such as time to maturity, coupon rate, trades on the normal yield price relationships, late payment penalty upon default, trading of debt-based sukuk and purchase undertaking in equity-based structures and therefore often resembles, conventional bonds (Taqi Usmani 2007; Lahsasna \& Lin 2012). The similarities of these features between conventional bonds and sukuk led market participants, the mass media, public policy makers and some academics to describe sukuk instruments as mimicking conventional bonds. Therefore, there is a tendency among practitioners to use sukuk interchangeably with conventional bonds.

Studies reveal strong empirical evidence that conventional bonds and sukuk yields (YTM) are different despite having a similar tenure in Malaysia (Safari 2011; Ariff, Safari \& Mohamed 2013; Safari \& Ariff 2014). However, these studies did not provide a wider range of yield movement (yield spreads) which cause the issuer to default on payment as well as not comparing the sukuk corporate yields with conventional bonds. Sukuk has an innovative and flexible structure compliant to the shariah principles by avoiding the riba, gharar, maisir and other prohibited elements should have a different pattern of yield spreads to that of conventional bonds. Furthermore, 
Karatas and Nienhaus (2015) commented that the series of these studies arrange a specifically paired sample for datasets measured in months (minimum for three months of issuances) and years (limited to 20 years only) provide biased comparison due to limited pairs and a larger range of pair samples in the observations. The long-term issuance is relatively lower than medium-term for each debt issuance. By considering these constructive comments on sample period, this study clustered the issuances based on long-term and medium-term for each debt issuance conventional bonds and sukuk matched with International Shariah Research Academy for Islamic Finance (ISRA) and Securities Commissions of Malaysia (SC). The clustered period are consistent with the data provided by the Bank Negara Malaysia (BNM) Bondinfo Hub website (2014) for Malaysian conventional bonds and sukuk market for the study period covering from 2000 to 2014 .

Sukuk, a relatively new asset class in global capital market, is facing a new challenge in the form of sukuk defaults like conventional bonds (Naifar \& Mseddi 2013), rather than structural problems or compliance with shariah law (Mat-Radzi \& Muhamed 2012). Therefore, an analysis of debt yield spreads as a measure of default risk is an important issue in investment since this is one, if not the only, key factor in determining the cost of external financing borne by the issuer of debt securities. The inabilities to meet interest obligations and the redemption of the principal when they become due will not only tarnish the issuing firm's corporate image, but more importantly, this will project a crisis of confidence among investors on the financial performance of the firm managed by the BOD. This situation leads to the discussion on the agency theory with respect to the separation of control and ownership and the issues arising from the agency cost of debt. Typically, higher cost of debt is associated with higher yield spreads which intuitively denote higher default risk among the issuer firms. In listed issuer firms, the growing dominance of equity holdings by institutional investors, both domestic and international, has recently sparked a debate on their role as effective shareholders in the monitoring of firms' performance and enforcing good corporate governance (Davis 2002). Here, many researchers focused on the impact of corporate governance mechanisms on bonds yield spreads performances whereby most studies did not distinguish them from sukuk (Bhojraj \& Sengupta 2003; Shailer \& Wang 2015; Akdogu \& Alp 2016). Thus, the outcome of these analyses may not be appropriate considering that the sukuk market has greatly developed and has come out with various sukuk products with unique features which are clearly distinguish its structure from conventional bonds. Therefore, the impact of corporate governance mechanisms on the yield spreads of sukuk might be different from conventional bonds in mediumterm and long-term issuances if the yield spreads between the two debts are not the same. Moreover, the presence of institutional ownerships and the BOD in corporate governance mechanisms will likely have a significant relation with medium-term and long-term conventional bonds and sukuk yield spreads among public listed issuers in Malaysia. Alternatively, one may also expect that the way corporate governance mechanisms impact the yield of sukuk is no difference to that of conventional bonds.

Considering the issues raised, this study focuses on the relationship of institutional ownerships and BOD in corporate governance mechanisms towards yield spreads as a default risk for public listed issuer in Malaysia. The research objectives are (1) to examine the relationship between the presence of institutional ownerships in conventional bonds and sukuk issuers with their yields spreads in medium-term and long-term issuances, and (2) to examine the relationship between BOD characteristics of the issuer with conventional bonds and sukuk yields spreads in medium-term and long-term issuances.

\section{LITERATURE REVIEW}

The Malaysia Code of Corporate Governance (MCCG) is a key document in Malaysia's corporate governance framework and has contributed significantly in improving the corporate governance standards of best practice for Malaysian listed companies. Over the years, companies have demonstrated a better appreciation of good governance and key stakeholders. Among others, institutional shareholders have increasingly taken on more definitive and prominent role in the domestic corporate governance sphere. Besides institutional ownership, the other important mechanism in the corporate governance is the function of the BOD. The BOD is central to corporate governance mechanisms in market economics. Along with external markets for corporate control and institutional and concentrated shareholdings, it is viewed as a primary means for shareholders to exercise control on top management (Fama \& Jensen 1983; Anderson, Mansi \& Reeb 2004; Ashbaugh-Skaife, Collins \& LaFond 2006; Bradley \& Chen 2011; Fields, Fraser \& Subrahmanyam 2012; Chen 2012) and separation of ownership and control leads to the corporate governance issues of management control and agency costs which require a centralised management delegated by shareholders to the BOD (Bohrer 2011).

There are limited empirical studies of sukuk investment compared to conventional bonds. Most of them claimed that the field of study is still new in the global market (Abd. Sukor, Muhamad \& Gunawa 2008; MatRadzi \& Muhamed 2012) and remain scarce in Malaysian studies even though Malaysia is a market leader in sukuk issuances (Grail 2007). Many conceptual studies have been conducted (Dusuki \& Abozaid 2007; Taqi Usmani 2007) by arguing the prohibition of charging excessive interest rate on sukuk yields but without reference to empirical data. This study can fill the gap by investigating the determinants that influence the conventional bonds and sukuk yield spreads. 


\section{INSTITUTIONAL OWNERSHIP AND YIELD PERFORMANCE}

The influence of institutional investors who have purchased and hold the corporate bonds and sukuk rather than individual investors might be a significant factor in yields determination. Institutional ownerships supposes active and greater monitoring and pressure more sensitive towards the performance of defaults risk as measured by yield spreads of conventional bonds and sukuk. Many researchers focused on the impact of corporate governance mechanisms on bonds yields performances (Bhojraj \& Sengupta 2003; Liu \& Jiraporn 2010; Tran 2014; Tanaka 2014; Dutordoir, Strong \& Ziegan 2014) and most of the studies did not distinguish between conventional bonds and sukuk.

The presence of active institutional investors in monitoring and controlling the management decisionmaking focus on public listed firms invested by government fiduciary bodies (Shailer \& Wang 2015; Abdul Wahab, How \& Verhoeven 2008) able to reduce cost of debt (Shailer \& Wang 2015; Sanchez-Ballesta \& Garcíameca 2011; Bhojraj \& Sengupta 2003) which consequently reduce the default risk (Bhojraj \& Sengupta 2003; Halim, How \& Verhoeven 2017). For instance, Sanchez-Ballesta and García-meca (2011) studied using a sample of Spanish listed firms indicating that ownership by the government in the listed firms have a relationship with the cost of debt whereby a higher level of ownership owned by them leads to having lower firm cost of debt.

However, the largest institutional ownerships need to collaborate with the management to ensure their monitoring role is significant to firm performance. For instance, Renneboog (1996) claimed that highly concentrated ownership closely controls companies with underperforming management however they do not aggressively participate in disciplining management. The finding is supported by Navissi and Naiker (2006) who postulated that institutional ownership as measured by active institutional investor (with board representation) and passive institutional investor (without board representation) have a relationship with firm value. Otherwise, they are not related to the value of the firm at lower levels of ownership. However, as the ownership increases, the impact on the value of the firm becomes negative with and without board representation respectively. Fields et al. (2012) also found a positive impact on the cost of capital debt financing if firms have a lower percentage of institutional ownership. With respect to the bond yield spreads, Boubakri and Ghouma (2010) explored the effect of governance on bond yield spreads in a multinational sample of firms. They found strong evidence that ultimate ownership had a significant positive effect on bond yield spreads. They concluded that a higher protection of bondholders' rights reduces bond yield spreads for financial firms when they hold and directly control the bonds.

Inversely, bond yields reported by Manconi, Massa and Yasud (2010) increased during economic crisis (2007-
2008) when corporate bonds are held by institutional investors. The result is consistent with Ertugrul and Hegde (2008) who utilised OLS regression multivariate analysis panel dataset covering observations for 783 firmyears. They reported that the percentage of institutional investors is negatively related to yield spreads. Implying that higher presence of these investors is able to reduce the default risk. Instead of captivating listed firms as a sample in their study, Fields et al. (2012) considered listed banks to investigate the relationship between institutional ownerships and the cost of bank debt. However, they report significant positive relation result. There were mixed results from the empirical studies when different or mixed samples are applied. Firms' enhancement in mitigating the default risks is important to improve performance. This is evident in Barry, Lepetit and Tarazi (2011) who analysed institutional investors who hold higher equity stakes in the firms and found that better performance was represented by lower default risk.

\section{BOARD OF DIRECTORS AND YIELD PERFORMANCE}

The agency theory, a dominant theory applied in corporate governance studies, is appropriate for conceptualising the monitoring and resource dependency in controlling roles of directors. The monitoring function refers to the responsibility of directors to monitor the actions of agents which refers to managers tasks in performing business management. Their decision-making is necessary to protect the interests of principals, i.e. the shareholders. The board serves as the representative for shareholders and is the primary internal control mechanism in aligning the conflicting interests of shareholders and management (Fama \& Jensen 1983; Jensen \& Meckling 1976; Marlin $\&$ Geiger 2012).

This is consistent with Pfeffer and Salancik (1978) who is claims that the resource dependence theory is derived from agency theory, which explains about the board's monitoring function that can reduce agency costs inherent in the separation of ownership and control issues. In this issue, Jensen and Meckling (1976) and Fama and Jensen (1983) claimed that the top common of the decision control systems of large or small organizations, in which decision agents do not bear a major share of the wealth effects of their decisions, is some form of BOD. Such BOD always has the power to hire fire and compensate the top-level decision managers and to ratify and monitor important decisions. Exercise of these top-level decision control rights by BOD helps to ensure separation of decision management and control even at the top of the organization (Fama \& Jensen 1983).

Johnson, Daily and Ellstrand (1996) by cited Selznick (1949) claimed that the earliest function of BOD can be viewed in resource dependency theory. The BOD function refers to governing board roles to minimize external uncertainty by exercising some level of control over the source of uncertainty. Thus, the theory establishes 
a theoretical foundation for the role of directors in providing advice and resources (Johnson et al. 1996; Garcia-Torea, Fernandez-Feijoo \& de la Cuesta 2016). They suggest that board effectiveness is determined by the external resources that individual members can draw for the benefit of the corporation. Directors reduce firm uncertainty by connecting the firm to the stakeholders. They provide advice and counsel, legitimacy, channels for communicating information to shareholders including institutional investor.

Furthermore, large shareholder action is channelled through the BOD. Large shareholders are in principle able to appoint board members representing their interests and exercise power by blocking ratification of unfavourable decisions, or possibly by initiating decisions when they have majority control of the board (Garcia-Torea et al. 2016; Chen, Hsu \& Chang 2016). Therefore, the involvement of the BOD in reducing the agency problem could minimise the issue in the agency cost of debt. This can be seen in the recent study by Alessandra, Rossi and Hussainey (2016) who discussed the role of the BOD in the agency theory perspective. They claimed that the BOD could work as an information system for stakeholders to monitor the firm's management decision.

Ahn and Shrestha (2013) classified boards into several characteristics such as board size, composition and CEO-Chairman functions. They found a significant negative relationship between board size and agency cost. Concerning board composition, they report that the adverse impacts of classified boards can be offset or even superseded by the potential benefits of board classification for firms that hope to benefit from the advisory services of their independent directors. They also report that firms with greater advising needs appoint more outside directors with diverse attributes, expertise, and qualifications that enhance the ability to provide useful advice to managers. Moreover, they claim that CEO-Chairman functions benefit firms that have low monitoring costs and greater needs for advisory services.

Therefore, the roles or functions of BOD in the theoretical, agency and resource dependency perspective according to the literature discussed above can be summariz into two main categories. First, BOD has administrative functions as explained by agency theory. For instance, to minimize external uncertainty (Bryant \& Davis 2012), Second, BOD have an environmental linking functions as explained by resource dependency theory. For instance, various independence resources (Pfeffer \& Salancik 1978) and organization power to access to scarce resources (Bryant \& Davis 2012) such as financing either in conventional or Islamic. Hence, both categories roles of board are existent in BOD characteristics as highlighted in corporate governance code of best practices to be complying.

\section{METHODOLOGY}

This study uses secondary data. The data gathered from various sources including BNM, RAM, SC, Bloomberg and Department of Statistics, Malaysia. Specifically, Data are retrieved from Bondinfo Hub's website from BNM for issue characteristics for conventional bonds and sukuk including yield, number of tranches, issuer name, price of debt, issue date, maturity date, issue amount in MYR' million and debt instrument categories. The detailed of the variables used and its measurement as well as the data sources is presented in Table 1 .

Next, all the data was sorted screened and matched. For missing information, data are then omitted. Therefore, the total usable observation data for the long-term debt instruments are 140 issuer firms with 256 tranches which cover from 2000 until 2014. In medium-term debt instruments, the total usable observation data are 160 issuer firms with 395 tranches from 2003 until 2014. Data on 2000 to 2002 were omitted due to being incomplete. Companies' annual reports were downloaded from the respective companies' website and Bursa Malaysia website. Some of the long-standing annual reports are not available in both websites. With that, this study collected the hard copy from the Knowledge Centre in Bursa Malaysia. An analysis of companies' annual report on a yearly basis was performed manually with the purpose of collecting data on institutional ownerships and the BOD characteristics.

\section{THEORIES AND HYPOTHESES DEVELOPMENT}

First, separation of decision and risk-bearing functions becomes an effective common approach to controlling the agency problems (Fama \& Jensen 1983) whereby the practise has been documented in the firms'corporate governance code. This code of best practise provides such recommendations to institutional investor for active monitoring and controlling cost direct to firms' management through BOD. These good recommendations of best practice are in consistent with the shariah law of Islamic principles (Abu-Tapanjeh 2009). Second, institutional ownership theory posits that institutional investors can act as a monitoring and control agents to overcome the agency problem that arise from the issue of separation and control (Demestz 1983) through their controlling and monitoring activities (Alireza \& Ali Tahbaz 2011). Thus, institutional investors are capable of influencing management performance which is driven by their ownership rights and ability to carry out share trading (Gillan \& Starks 2003). Third, resource dependency theory is a major grounded theoretical in explaining about the BOD function that have an authority power on top management decision making for financing decision in reducing agency cost of debt (Pfeffer \& Salancik 1978; Marlin \& Geiger 2012). 
TABLE 1. Data description

\begin{tabular}{|c|c|c|c|c|c|}
\hline No & Variables & Description & Proxy/Measurement & Predicted & Data \\
\hline \multicolumn{6}{|c|}{ Dependent: } \\
\hline 1 & Yield Spreads & YTM & $\begin{array}{l}\text { Max of YTM minus min of YTM of bonds \& } \\
\text { sukuk issues minus with T-bills on matched } \\
\text { issuance date for long- and medium-term issued. }\end{array}$ & & BNM, RAM \& SC \\
\hline \multicolumn{6}{|c|}{ Independent: } \\
\hline \multicolumn{6}{|c|}{ Institutional Ownerships: } \\
\hline 2 & Top-Six IO & Gov & $\begin{array}{l}\text { The total percentage of share ownership by six } \\
\text { institutional owners of public listed firms. }\end{array}$ & - & Annual Report \\
\hline 3 & Others IO & All IO & $\begin{array}{l}\text { The total percentage of share ownership by all inst. } \\
\text { owners of public listed firms except top- } 6 \text { IO. }\end{array}$ & - & \\
\hline \multicolumn{6}{|c|}{ BOD Characteristics: } \\
\hline 4 & BODR2 & $\begin{array}{l}\text { CEO \& } \\
\text { chairman }\end{array}$ & $\begin{array}{l}\text { Dichotomous variable. } 1 \text { if combined position } \\
\text { of CEO and chairman and } \mathrm{O} \text { if separated position. }\end{array}$ & - & Annual Report \\
\hline 5 & BODC & \# of directors & $\begin{array}{l}\text { Dichotomous variable. } 1 \text { if independent director } \\
\text { less than } 1 / 3 \text { and } 0 \text { if independent director } \\
=@>1 / 3 \text {. }\end{array}$ & - & \\
\hline 6 & BODS & \# of directors & Total number of directors in the firm. & - & \\
\hline 7 & BODM & $\begin{array}{l}\text { Muslim } \\
\text { directors }\end{array}$ & $\begin{array}{l}\text { Total percentage for number of Muslim directors } \\
\text { over total number of directors. }\end{array}$ & ? & \\
\hline \multicolumn{6}{|c|}{ 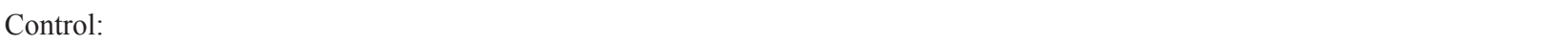 } \\
\hline 8 & Volatility & Price of debt & $\begin{array}{l}\text { Maximum minus minimum price for each } \\
\text { tranches of conventional bonds and sukuk. }\end{array}$ & + & BNM, RAM \& SC \\
\hline 9 & $\operatorname{lnSize}$ & Issue & log of amount of issue in MYR (millions). & - & \\
\hline 10 & Tenure & Year & Maturity year period minus with issue year period. & + & \\
\hline 11 & Profit & ROA & Net income divided by total assets. & + & Bloomberg \\
\hline 12 & Leverage & $\mathrm{TA} / \mathrm{TE}$ & Total assets divided by total equity. & - & \\
\hline 13 & Firm Value & Tobin's Q & $\begin{array}{l}\text { Total of market value of equity with book value } \\
\text { preferred stock and book value of LTD/TA. }\end{array}$ & $\begin{array}{l}+ \\
+\end{array}$ & \\
\hline 14 & Firm Size & $\ln \mathrm{TA}$ & Log of total short-term assets and long-term assets. & + & \\
\hline 15 & Sustain & SGR & $\begin{array}{l}\text { Return on common shares equity times with one } \\
\text { minus dividend payout ratio over } 100 \text {. }\end{array}$ & - & \\
\hline 16 & $\operatorname{lnGDP}$ & $\begin{array}{l}\text { Current } \\
\text { Prices }\end{array}$ & $\begin{array}{l}\text { Log of current price of Malaysian gross domestic } \\
\text { product for each year issued. }\end{array}$ & - & Msians Statistics \\
\hline
\end{tabular}

In line with the agency and ownership theorists as well as the aforementioned empirical evidence, hypothesis 1 and 2 is suggested as follows:

$\mathrm{H}_{1} \quad$ Firms with greater presence of top-six institutional ownership have lower conventional bonds/sukuk yield spreads than firms with a lower presence of top-six institutional ownership in the long-term and mediumterm investment.

$\mathrm{H}_{2}$ Firms with greater presence of other institutional ownership have lower conventional bonds/sukuk yield spreads than firms with lower presence of other institutional ownership in long-term and mediumterm investment.

Then, this study developed hypotheses 3 to 6 on the relationships between BOD characteristics with yield spreads of conventional bonds and sukuk to satisfy the third objective of the study. Many researchers remark that those board members who hold two positions face numerous problems. Judge, Naoumova and Koutzevol (2003) mentioned that CEO chairs the group of people in monitoring and evaluating the CEO's performance. Here, the conflicts of interest in the agency theory arise whereby the CEO monitors and evaluates his/her performance in that particular company. Furthermore, combined leadership structure in role duality is negatively related to firm performance (Judge et al. 2003) which supports the predictions of agency theory. Liu and Jiraporn (2010) found that the CEO who has more decision-making power was associated with higher yield spreads. Based on the abovementioned theoretical views and empirical evidence, it is hypothesised as follows:

$\mathrm{H}_{3} \quad$ Firms with a separate board of directors' role duality have lower conventional bonds/sukuk yield spreads than firms with the combined board of directors' role duality in long-term and medium-term investment.

$\mathrm{H}_{4}$ Firms with more than one-third of independent directors have lower conventional bonds/sukuk yield spreads than firms with less than one-third of independent directors in long-term and medium-term investment.

$\mathrm{H}_{5} \quad$ Firms with larger board size have lower conventional bonds/sukuk yield spreads than firms with less board size in long-term and medium-term investment. 
$\mathrm{H}_{6}$ Firms with higher BOD Muslim have lower sukuk yield spreads than conventional bonds in long-term and medium-term investment.

\section{MULTIVARIATE PANEL ROBUST REGRESSIONS (MPRR)}

Testing the relationship among these variables is considered as an estimations models for the MPRR used in this study. This model is developed based on debt instrument categories for long-term and medium-term conventional bonds and sukuk. Different types of issuances have a different effect on default risk. Besides, the effect in pooled OLS, within the firm as fixed effect or random effect is tested for each panel observation in conventional bonds and sukuk.

The OLS model has treated standard error of estimations represented by $\varepsilon$ as identically and independently distributed disturbances that are uncorrelated with the correlations of standard error for independent variables, $\chi$ or $\operatorname{Cor}\left(\varepsilon_{i}, X\right)=0$. In this case, the data can be pooled, and OLS can be used to estimate the model with denoting the estimator of the slope by $\beta_{O L S}$. The intercept and slope coefficients are constant across $\mathrm{N}$ and $\mathrm{T}$ represented by tranche issuances of each issuer which postulates that both the intercept and the slope are the same across observations. However, these assumptions might be restrictive and lead to heterogeneity bias needed to handle the robustness checks analysis. Otherwise, the model does not require any additional technique for such estimations. The regression model equation for pooled oLs can be represented as follows:

YieldSpreds $_{i t}=\beta_{\text {OLS }}+\beta_{\text {OLS }}\left(\right.$ Top - sixIO $\left._{i t}\right)+\beta_{\text {OLS }}\left(\right.$ OthersIO $\left.I_{i t}\right)$ $+\beta_{O L S_{3}}\left(B O D R_{i t}\right)+\beta_{O L S_{4}}\left(B O D C_{i t}\right)+\beta_{O L S_{5}}\left(B O D S_{i t}\right)+\beta_{O L S_{6}}$ $\left(B O D M_{i t}\right)+\beta_{\text {OLS }}\left(\right.$ Volatility $\left._{i t}\right)+\beta_{\text {OLS }}\left(\right.$ InSize $\left._{i t}\right)+\beta_{\text {OLS }}$ $\left(\right.$ Tenure $\left._{i t}\right)+\beta_{\text {OLS }}\left(\right.$ profit $\left._{i t}\right)+\beta_{\text {OLS }}$ Leverage $\left._{i 1}\right)+\beta_{\text {OLS }}$ $\left(\right.$ Firm Value $\left._{i t}\right)+\beta_{\text {oLs }}\left(\right.$ FirmSize $\left._{i t}\right)+\beta_{\text {oLS }}\left(\right.$ Sustain $\left._{i t}\right)+$ $\beta_{O L S_{15}}\left(\operatorname{InGDPe_{it}}\right)+\varepsilon_{i t}$

Then, the fixed effect model used is when the constant value for each tranche of issuances, $x_{i t}$ is correlated with the independent variables of the issuers for the year, and within variation in the data only, but is the most flexible in that it allows for the endogeneity of regressors. This model also treats $\lambda_{i}$ as a constant value for each tranche of issuances. Where:

$\beta_{f e}=$ the coefficient estimates in fixed effect of the explanatory variables

$\left(\beta_{f e}+\lambda_{i}\right)=$ the intercept for fixed effect, and

$u_{i t}=$ the error term for fixed effect.

With respect to the random effect model model, it assumes that the tranche of issuances has their intercepts while restricting the slope to be homogenous for yield spreads. Their spread is probably in random-effect as liquidity movement which required technique of these regressions as applied by Said et al. (2013) in their study. To accommodate such heterogeneity, the random-effect model decomposes the into two composite error term as $\varepsilon_{i t}=\lambda_{i}+u_{i t}$

\section{STATISTICAL TESTS FOR PANEL MODEL SELECTION}

In this section, statistical tests for panel model selection and multivariate regression results were reported in Table 3 and 4. As discussed earlier, pooled oLs estimator is easy to use for estimating regression model but it does not capture the unobservable individual heterogeneity. In this case, fixed effect and random-effect estimators are used. This variety of approaches leaves the question about which model is the most appropriate in explaining the result for findings in Table 3. This can be solved by performing two statistical tests on the regression model. These are the Breusch and Pagan Lagrangian Multiplier Test (BP-LM) and Hausman Test. The BP-LM test tests for the existence of individual specific variance component or heterogeneity whether the pooled OLS is an appropriate model or not in interpreting the result. This test is important to discriminate between the pooled OLS and Generalized Least Squared (GLS) or random-effect model. The presence of the individual specific term, which distinguishes between these models, is based on the following statistical hypotheses:

$$
\begin{aligned}
& H_{0}: \sigma_{\lambda}^{2}=0 \quad \ldots \text { (Pooled OLS) } \\
& H_{a}: \sigma_{\lambda}^{2} \neq 0 \quad \ldots \text { (Random effects) }
\end{aligned}
$$

The Lagrangian Multiplier (LM) statistic follows the chi-squared distribution with one degree of freedom as shown by equation as follows:

$$
L M=\frac{n T}{2(T-1)}\left[\frac{T^{2} \bar{e}^{\prime} \bar{e}}{e^{\prime} e}-1\right]^{2} \sim \chi^{2}(1)
$$

Where:

$\bar{e}=$ the $n \times 1$ vector of the group means of pooled regression residuals,

$e^{\prime} e=$ the goodness-of-fit measure or R-squared of the pooled OLS regression,

$\chi=$ the correlations of standard error for independent variables,

$T=$ the total periods, and

$n=$ the number of periods.

If the null hypothesis is rejected whereby the p-value is less $0.01,0.05$ or 0.1 , it means that the random-effect model in unbalanced panel data is more appropriate than pooled OLS estimations since it is able to deal with heterogeneity (Breusch \& Pagan 1980; Baltagi 2001). Even if they are uncorrelated with the regressors, the random-effect estimator will deliver a consistent estimator that is also efficient. However, the results may be inconsistent or biased. In such a case, the study runs the Hausman test. The test was developed by Hausman (1978) for the purpose to distinguish between random-effect and 
fixed-effect model. Therefore, the hypotheses can then be modified as follows:

$$
\begin{aligned}
& H_{0}:\left(\hat{\beta}_{f e}-\hat{\beta}_{r e}\right)=0 \\
& H_{a}:\left(\hat{\beta}_{f e}-\hat{\beta}_{r e}\right) \neq 0
\end{aligned}
$$

\section{RESULTS}

\section{DESCRIPTIVE STATISTICAL RESULTS}

The minimum value trend demonstrates a similar pattern to the mean value. Meaning that all the issuances tranche have competitive rate of yields during the contract initiated. However, only MTCBS, LTB, MTCB and MTS show a similar pattern for maximum value. But, the LTCBS and LTS show different patterns indicating a very high cost showed by value of yield spreads from LTS at $18.06 \%$. Notably, the yield is refers to the different of maximum and minimum value for YTM which indicates the range of yield spreads. The finding is consistent with the theory of term structure of interest rate whereby longer periods have higher interest rate hence wider range of spreads are associated with higher default risks.

TABLE 2. The results of mean, maximum and minimum of yield spreads

\begin{tabular}{ccccc}
\hline Yield Spreads & LTB & LTS & MTCB & MTS \\
\hline Mean & 2.44 & 1.95 & 1.43 & 1.69 \\
Max & 7.33 & 18.06 & 4.98 & 5.16 \\
Min & 0.08 & -0.52 & 0.02 & -0.2 \\
\hline
\end{tabular}

\section{STATISTICAL SELECTION TESTS RESULTS}

As a result of LTCB in Table 3, the BP-LM test show that chibar-squared is 1.290 with the probability is an insignificant result. Thus, the null hypothesis failed to be rejected suggesting that the pooled oLS model is more appropriate than random-effect model. This denotes that pooled OLS model is better suited for such analysis whereby the assumption of pooled OLS model about the error term leading to have serial correlation between observations and might be in the presence of unobservable individual heterogeneity are applied in this sample. Since the pooled OLS model has been selected, the model does need to be compared with the fixed effects model using the Hausman test. It is also not required to perform heterokedasticity diagnostic check test since the model has the ability to rectify the presence of unobservable individual heterogeneity. Therefore, the results from pooled OLS model are better suited for the analysis in LTCB. As for LTS, the null hypothesis is rejected suggesting that the random-effect model is more appropriate than pooled OLS model. Consequently, BPLM test confirms that RE robust model estimator is the selection model and as regards to the result of Hausman test, the chi-squared is 22.120 indicates insignificant result lead the decision to reject the null hypothesis.

Thus, the test confirms that random-effect for regression estimations model is the most appropriate compared with fixed-effect model in analysing the relationship of yield spreads towards their determinants. Pertaining to the selection model tests result for MTCB, the BP-LM test show that the chibar-squared is 1.290 with the probability is insignificant result. Thus, the null hypothesis failed to be rejected suggesting that the pooled OLS model is more appropriate than random-effect model. The result concludes that the RE robust model is the most appropriate model in analysing the relationship between yield spreads and its explanatory variables for MTS.

\section{ROBUST REGRESSION ANALYSIS}

Institutional Ownership and Yield Spreads Table 4 shows the overall results of model selection with significant relationship between institutional ownerships

\begin{tabular}{|c|c|c|c|c|c|c|c|c|c|}
\hline \multirow[b]{3}{*}{ Panel } & \multirow[b]{3}{*}{ Model } & \multicolumn{4}{|c|}{ Test } & \multirow{2}{*}{\multicolumn{3}{|c|}{$\begin{array}{l}\text { Diagnostic Checks } \\
\text { Heterokedasticity } \\
\end{array}$}} & \multirow{3}{*}{$\begin{array}{c}\text { Most } \\
\text { Appropriate } \\
\text { Model }\end{array}$} \\
\hline & & \multicolumn{2}{|l|}{ BP-LM } & \multicolumn{2}{|c|}{ Hausman } & & & & \\
\hline & & Chibar-squared & Prob. & Chi-squared & Prob. & Model & Chi-squared & $\overline{\text { Prob. }}$ & \\
\hline \multirow[t]{3}{*}{ A: LTCB } & OLS & 1.290 & 0.128 & - & - & OLS & 156 & 0.000 & OLS \\
\hline & $\mathrm{RE}$ & & 工 & 73.460 & 0.000 & & & & \\
\hline & FE & - & - & & & & & & \\
\hline \multirow[t]{3}{*}{ B: LTS } & OLS & 6.620 & 0.005 & - & - & $\mathrm{RE}$ & 965 & 0.000 & RE Robust \\
\hline & $\mathrm{RE}$ & & - & 22.120 & 0.105 & & & & \\
\hline & $\mathrm{FE}$ & - & - & & & & & & \\
\hline \multirow[t]{3}{*}{ C: МTCB } & OLS & 1.870 & 0.086 & - & - & OLS & 9800000 & 0.000 & OLS \\
\hline & $\mathrm{RE}$ & 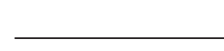 & - & 87.580 & 0.000 & & & & \\
\hline & $\mathrm{FE}$ & - & - & & & & & & \\
\hline \multirow[t]{2}{*}{ D: MTS } & OLS & 74.380 & 0.000 & - & - & $\mathrm{RE}$ & 110000 & 0.000 & RE Robust \\
\hline & $\mathrm{RE}$ & & & 23.610 & 0.072 & & & & \\
\hline
\end{tabular}

TABLE 3. The results of BP-LM, Hausman and Heterokedasticity test 
TABLE 4. The results of robust regression

\begin{tabular}{|c|c|c|c|c|}
\hline Debt Instrument & Panel A: LTCB & Panel B: LTS & Panel C: MTCB & Panel D: MTS \\
\hline \multicolumn{5}{|c|}{ Dependent variable: Yield Spreads } \\
\hline \multirow[t]{2}{*}{ Explanatory variables } & \multicolumn{4}{|c|}{ Model } \\
\hline & OLS & RE Robust & OLS & RE Robust \\
\hline Intercept & -0.307 & 4.881 & $21.030 * * *$ & $31.350 * * *$ \\
\hline \multicolumn{5}{|c|}{ Institutional Ownerships: } \\
\hline Top-six IO & 0.001 & -0.079 & -0.001 & 0.001 \\
\hline Others IO & 0.01 & $-0.110 *$ & $-0.010 * *$ & -0.003 \\
\hline \multicolumn{5}{|c|}{ Board of Directors Characteristics: } \\
\hline BODR2 & 0.662 & $3.249 * *$ & $0.484 *$ & -0.407 \\
\hline BODC & -0.209 & 0.609 & 0.093 & -0.167 \\
\hline BODS & 0.076 & 0.063 & $-0.076 * *$ & $0.120 * *$ \\
\hline BODM & $0.018 *$ & -0.037 & $-0.015 * * *$ & -0.005 \\
\hline \multicolumn{5}{|l|}{ Issue Characteristics: } \\
\hline Volatility & 0.03 & $0.262 * *$ & $0.243 * *$ & 0.005 \\
\hline $\operatorname{lnSize}$ & -0.095 & -0.198 & $-0.148 * *$ & $-0.062 *$ \\
\hline Tenure & 0.003 & $0.074 * *$ & 0.034 & $0.113 * * *$ \\
\hline \multicolumn{5}{|l|}{ Issuer Characteristics: } \\
\hline Profit & $0.072 *$ & -0.129 & $-0.100 * * *$ & 0.028 \\
\hline Leverage & -0.062 & $0.857^{*}$ & $-0.048 * *$ & 0.056 \\
\hline Firm Value & 0.068 & 0.819 & $0.392 * *$ & $-0.840 * *$ \\
\hline Firm Size & 0.008 & -0.493 & 0.031 & -0.069 \\
\hline Sustain & -0.024 & 0.124 & $0.025^{* *}$ & $0.001 * * *$ \\
\hline \multicolumn{5}{|l|}{ Systematic Risks: } \\
\hline $\operatorname{lnGDP}$ & 0.082 & 0.275 & $-1.289 * * *$ & $-2.159 * * *$ \\
\hline Firm fixed effects & No & No & No & No \\
\hline No of observations & 112 & 144 & 157 & 244 \\
\hline R-squared & 0.2503 & 0.5349 & 0.4963 & 0.544 \\
\hline Adj R-squared & 0.1331 & - & 0.4427 & - \\
\hline Model Fit (F-stat) & $2.14 * *$ & - & $9.26 * * *$ & - \\
\hline F-test & - & - & - & - \\
\hline Wald-chi-squared & - & $58898.15^{* * *}$ & - & $442.97 * * *$ \\
\hline
\end{tabular}

with the yield spreads for all terms of conventional bonds and sukuk issuances. With respect to other institutional ownerships, there are mixed and inverse results revealed by conventional bonds and sukuk. Two panels data are met with the hypothesis developed, for instance; panel B and C for others institutional ownership but none for top-6. This implies that, the presence of other institutional ownerships is significant to reduce yields spreads in long-term sukuk and medium-term conventional bonds issuance.

Board of Directors and Yield Spreads The overall results of relationship between BOD characteristics with the yield spreads for all terms of conventional bonds and sukuk issuances have significant impact. With respect to the BOD role duality, it shows a significant relationship with panel $\mathrm{B}$ and C. Vindicating that, the separation role between chairman of directors and CEO are important determinants towards sukuk in long term, otherwise conventional bonds for medium-term issuances. Otherwise, this separate position is significant to the issuer in mitigating default risks when the medium term sukuk and long term conventional bond' issued.
Next, BOD composition shows insignificant relationships towards yield spreads in all types of debt issuances for conventional bonds or sukuk. Thus, the hypothesis 4 is rejected. As regards to BOD size, the finding shows that panel $\mathrm{C}$ and $\mathrm{D}$ have significant relationships towards yield spreads. It means that BOD size becomes a very important determinant to yield spreads especially in medium-term for both issuances either conventional bonds or sukuk. This denotes that larger size lead to higher yield spread in medium-term issuances. Too many directors are not good whereby conflict of interest may arise in decision making (Dutordoir et al. 2014). With respect to the BOD Muslim, unpredictably, higher numbers of Muslim directors have significant relation with yield spreads of conventional bonds issuances for both long-term and medium-term. In contrast, sukuk yield spreads indicate insignificant relationship with BOD Muslim.

\section{MANAGERIAL IMPLICATION}

There are four important implications on managerial issues by BOD among issuer firms. Firstly, agency theory 
highlights the roles of BOD as an agent on behalf of the principal to manage the firms. The management by these parties supposedly aligns with the Islamic principles to produce effective management which then lead to reducing default risks. Secondly, separating the chairman and CEO has managerial implications on their capabilities to focus on the business management of the company which is associated with a reduction in yield spreads. Thirdly, larger board size provides more skills that can endeavour to enhance firm performance in monitoring and advising functions that contribute to low default risks. Fourthly, the presence of more than one-third independent directors in the firm is unable to mitigate the default risks. Even though the MCCG suggests that the most effective board balance and no individual or small group of individuals can dominate the board's decision beside have an ability to exercise a majority of votes for the election of directors, it has no effect on yield spreads.

Next, this study serves two categories of academic theory between conventional theory and Islamic principles. It merges and matches both categories which might be dual practice and consistent with the corporate governance code of best practice. Sukuk investment applies the halal theory in not only this investment financing product, but also the way of dealing with cost charging and how to manage and monitor the investment performance based on Islamic principles. Sukuk-holders demand halal investment to achieve Maqasid Al-Shariah encourage the issuer for both either under shariah or non-Shariah securities firms to offer or issue sukuk. These sukuk can mitigate the default risks, and the demand is expected to be increased in future.

In overall, the study provides a new contribution on Islamic corporate governance as it might share similar features with Western corporate governance perspectives; however, the interest of stakeholders in Islamic context is beyond the financial return as it also covers shariah rulings or Islamic law and principle of Tawhid. In this principle, according to Chapra (1992), the stakeholders as vicegerent (Khilafah) of Allah swT have fiduciary duty to uphold the principle of justice distribution through the of shariah's board and mutual interest of group's participation as part of corporate governance.

\section{CONCLUSION}

The presence of top-six institutional ownerships is unable to reduce default risks facing the issuer; however, the presence of other institutional ownerships can reduce default risks among issuers who issue sukuk for longterm issuances and conventional bonds for medium-term issuances. BOD characteristics such as role duality, the number of directors and director's religion appear to be significant determinants in influencing yield spreads except for the composition of independent directors in the firms. These findings offer recommendations to the issuer as well as institutional investors and the BOD.
Firstly, recommendations focus on public listed issuer since they are actively involved in the capital market by issuing debt to the public. In long-run investment, they are encouraged to issue sukuk as compared to conventional bonds since the default risk is low. This justifies that the cost of sukuk is lower than the cost of debt in long-term issuances since spreading in sukuk yields is lower as riba or uncertainty elements is avoided. Secondly, the presence of institutional ownerships in the issuer firms has a relationship with high-low yield spreads. Their presence would enhance effective monitoring and control in the firm's decision-making, especially in financing matters. Thirdly, to avoid abuse of power, biased decision and conflict of interest, the separation role between chairman and CEO to a different person is important even though the duties and responsibilities of this position are clearly highlighted in the MCCG. If it is still required, they not only need to follow the job descriptions of the position respectively but more importantly need to comply with Islamic principles especially Muslim BOD.

\section{REFERENCES}

Abd. Sukor, M.E., Muhamad, R. \& Gunawa, A.Y. 2008. Malaysian sukuk: Issues in Accounting Standard. Shariah Journal 16(1): 63-74.

Abdul Wahab, E.A., How, J. \& Verhoeven, P. 2008. Corporate governance and institutional investors: evidence from Malaysia. Asian Academy of Management Journal of Accounting and Finance (AAMJAF) 4(2): 67-90.

Abu-Tapanjeh, A.M. 2009. Corporate governance from the Islamic perspective: A comparative analysis with OECD principles. Critical Perspectives on Accounting 20: 556567.

Ahn, S. \& Shrestha, K. 2013. The differential effects of classified boards on firm value. Journal of Banking \& Finance 37 : 3993-4013.

Alessandra, A., Rossi, F.M. \& Hussainey, K. 2016. The board's role in risk disclosure: An exploratory study of Italian listed state-owned enterprises. Public Money \& Management 36(2): 113-120.

Alireza, F. \& Ali Tanbaz, H. 2011. The examination of the effect of ownership structure on firm performance in listed firm of Tehran Stock Exchange based on the type of industry. International Journal of Business and Management 6(3): 249-266.

Anderson, R.C., Mansi, S.A. \& Reeb, D.M. 2004. Board characteristics, accounting report integrity, and the cost of debt. Journal of Accounting and Economics 37: 315-342.

Akdoğu, E. \& Alp, A. 2016. Credit risk and governance: Evidence from credit default swap spreads. Finance Research Letters 17: 211-217.

Ariff, M., Safari, M. \& Mohamad, S. 2013. Sukuk securities and conventional bonds: Evidence of significant differences. Pertanika Journal of Social Science and Humanities 21(2): 621-638.

Ashbaugh-Skaife, H., Collins, D.W. \& LaFond, R. 2006. The effects of corporate governance on firms' credit ratings. Journal of Accounting and Economics 42(1-2): 203-243.

Baltagi, B.H. 2001. Econometric Analysis of Panel Data. 2nd edition. New York: Wiley. 
Barry, T.A., Lepetit, L. \& Tarazi, A. 2011. Ownership structure and risk in publicly held and privately owned banks. Journal of Banking \& Finance 35: 1327-1340.

Bhojraj, S. \& Sengupta, P. 2003. Effects of corporate governance on bond ratings and yields: The role of institutional investors and outside directors. Journal of Business 76: 455-476.

Bloomberg. 2015. Bond market. Available at https://www. bloomberg.com/graphics/2015-the-year-in-money/

Boubakri, N. \& Ghouma, H. 2010. Control/ownership structure, creditor rights protection, and the cost of debt financing: International evidence. Journal of Banking \& Finance 34(10): 2481-2499.

Bradley, M. \& Chen, D. 2011. Corporate governance and the cost of debt: Evidence from director limited liability and indemnification provisions. Journal of Corporate Finance 17: 83-107.

Bryant, P. \& Davis, C. 2012. Regulated change effects on board of directors: A look at agency theory and resource dependency theory. Academy of Strategic Management Journal 11(2): 1-16.

Breusch, T.S. \& Pagan, A.R. 1980. The lagrange multiplier test and its applications to model specification in econometrics. The Review of Economic Studies 47(1): 239-253.

Chapra, M.U. 1992. Islam and the economic challenge. Islamic Economics Series 17, the Islamic Foundation, Nigeria Available at http://ierc.sbu.ac.ir/File/Article/Islam\%20and\% 20the $\% 20$ Economic $\% 20$ Challenge 93524.pdf

Chen, D. 2012. Classified boards, the cost of debt, and firm performance. Journal of Banking \& Finance 36: 33463365

Chen, H-L., Hsu, W-T. \& Chang, C-Y. 2016. Independent directors' human and social capital, firm internationalization and performance implications: An integrated agencyresource dependence view. International Business Review 25: 859-871

Davis, E.P. 2002. Institutional investors, corporate governance and the performance of the corporate sector. Economic Systems 26: 203-229.

Demsetz, H. 1983. The structure of ownership and the theory of the firm. The Journal of law \& Economics 26(2): 375390.

Dusuki, A.W. \& Abozaid, A. 2007. A critical appraisal on the challenges of realising Maqasid al-Shari ah in Islamic Banking and Finance. IIUM Journal of Economics and Management 15(2): 143-165.

Dutordoir, M., Strong, N. \& Ziegan, M.C. 2014. Does corporate governance influence convertible bond issuance?. Journal of Corporate Finance 24: 80-100.

Ertugrul, M. \& Hegde, S. 2008. Board compensation practices and agency costs of debt. Journal of Corporate Finance 14: $512-531$.

Fama, E.F. \& Jensen, M.C. 1983. Separation of ownership and control. Journal of Law and Economics 26: 301-325.

Fields, L.P., Fraser, D.R. \& Subrahmanyam, A. 2012. Board quality and the cost of debt capital: The case of Bank Loans. Journal of Banking \& Finance 36: 1536-1547.

Garcia-Torea, N., Fernandez-Feijoo, B. \& de la Cuesta, M 2016. Board of director's effectiveness and the stakeholder perspective of corporate governance: Do effective boards promote the interests of shareholders and stakeholders? BRQ Business Research Quarterly 19: 246-260.

Grail. 2007. Overview of Islamic finance. Available at http:// www.grailresearch.com/pdf/ ContenPodsPdf/Islamic Finance_Overview.pdf
Gillan S.L. \& Starks L.T. 2003. Corporate governance, corporate ownership and the role of institutional investors: A global perspective. Journal of Applied Finance 13(2): 4-22.

Halim, Z.A., How, J. \& Verhoeven, P. 2017. Agency costs and corporate sukuk issuance. Pacific-Basin Finance Journal 42: 83-95.

Hausman, J.A. 1978. Specification tests in econometrics. Econometrica 46(6): 1251-1271.

International Islamic Financial Market (IIFM). 2012. IIFM Annual Report 2012. Available at www.iifm.net/about iifm/financial-statements

International Monetary Fund (IMF). 2005. The Annual Report 2005 to the Board of Governors reviews the IMF's activities and policies during the financial year (May 1, 2004, through April 30, 2005).

International Shariah Research Academy for Islamic Finance (ISRA) \& Securities Commission of Malaysia (SC). 2015. Islamic Capital Markets: Principles \& Practices. Pearson.

Jensen, M.C. \& Meckling, W.H. 1976. Theory of the firm: Managerial behavior, agency costs and ownership structure. Journal of Financial Economics 3(4): 305-360.

Johnson, J.L., Daily, C.M. \& Ellstrand, A.E. 1996. Board of directors: A review and research agenda. Journal of Management 22(3): 409-438.

Judge, W.Q., Naoumova, I. \& Koutzevol, N. 2003. Corporate governance and firm performance in Russia: An empirical study. Journal of World Business 38: 385-396.

Karatas, A. \& Nienhaus, V. 2015. Comparing sukūk and conventional securities: The challenge of consistency. Journal of Islamic Banking and Finance 3(2): 15-23.

Khan, T. \& Ahmad, H. 2001. Risk management: An analysis of issues in the Islamic Financial Industry. Jeddah: IRTI Occasional Paper \# 5.

Lahsasna, A. \& Lin, L.S. 2012. Issues in Islamic Capital Markets: Islamic Bond/ Sukuk. 3rd International Conference on Business and Economic Research (3rd ICBER 2012) Proceeding, 495-512.

Liu, Y. \& Jiraporn, P. 2010. The effect of CEO power on bond ratings and yields. Journal of Empirical Finance 17(4): 744-762.

Manconi, A., Massa, M. \& Yasuda, A. 2010. The behavior of intoxicated investors: The role of institutional investors in propagating the crisis of 2007-2008. Available at http:// dx.doi.org/10.2139/ssrn. 1659547

Marlin, D. \& Geiger, S.W. 2012. The composition of corporate boards of directors: Does industry matter?. Journal of Business \& Economics Research 10(3): 157-162.

Mat-Radzi, R. \& Muhamed, N.A. 2012. An international comparative study on Shariah governance supervision of sukuk defaults. Journal of Islamic Economics, Banking and Finance 8-22(3): 20-43.

Naifar, N. 2016. Modeling dependence structure between stock market volatility and sukuk yields: A nonlinear study in the case of Saudi Arabia. Borsa Istanbul Review 16(3): $157-166$.

Naifar, N. \& Mseddi, S. 2013. Sukuk spreads determinants and pricing model methodology. Afro-Asian Journal of Finance and Accounting 3(3): 241-257.

Navissi, F. \& Naiker, V. 2006. Institutional ownership and corporate value. Managerial Finance 32(3): 247-256.

Pfeffer, J. \& Salancik, G.R. 1978. The design and management of externally controlled organizations. The External Control of Organizations: 257-287. 
Renneboog, L. 1996. Ownership, managerial control and the governance of companies listed on the Brussels Stock Exchange. Working Paper 9635. Available at http://dx.doi. org/10.2139/ssrn.2115

Safari, M. 2011. Are Sukuk securities the same as conventional bonds?.Proceedings of Foundation of Islamic Finance Series, Second Conference, March 8-10. Kuala Lumpur, Malaysia.

Safari, M. \& Ariff, M. 2014. Does market differentiate between sukuk and bonds. Journal of Money, Investment and Banking 29: 104-119.

Said, A. \& Grassa, R. 2013. The determinants of sukuk market development: Does macroeconomic factors influence the construction of certain structure of sukuk? Journal of Applied Finance \& Banking 3(5): 251-267.

Said, R., W. Suhaimi, W.N. \& Haris, A. 2013. Determinants of Islamic Bond (Sukuk): Evidence in Malaysia. Available at http://dx.doi.org/10.2139/ssrn.2311835

Sanchez-Ballesta, J.P. \& Garcia-Meca, E. 2011. Ownership structure and the cost of debt. European Accounting Review 20(2): 389-416.

Shailer, G. \& Wang, K. 2015. Government ownership and the cost of debt for Chinese listed corporations. Emerging Markets Review 22: 1-17.

Tanaka. 2014. Corporate governance and the cost of public debt financing: Evidence from Japan. Journal of the Japanese and International Economies 34: 315-335.

Taqi Usmani, M. 2007. Sukuk and their contemporary applications. (Translated from the original Arabic by Sheikh Yusuf Talal DeLorenzo). AAOIFI Shari'a Council Meeting, Saudi Arabia. Available at: http://www.kantakji. com/media/7747/f148.pdf
Tariq, A.A. \& Dar, H. 2007. Risks of sukuk structures: Implications for resource mobilization. Thunderbird International Business Review 49(2): 203-223.

Thomson Reuters. 2015. Thomson Reuters Reports First-Quarter 2015 Results. Available at https://www.thomsonreuters. com/en/press-releases/2015/april/thomson-reuters-reportsfirst-quarter-2015-results.html

Tran, D.C. 2014. Multiple corporate governance attributes and the cost of capital- Evidence from Germany. The British Accounting Review 46: 179-197.

Noriza Mohd Saad (corresponding author)

Department of Finance \& Economics

Universiti Tenaga Nasional

26700 Muadzam Shah, Pahang, MALAYsiA.

E-Mail: Noriza@uniten.edu.my

Mohd Nizal Haniff

Faculty of Accountancy

Universiti Teknologi MARA

40450 Shah Alam, Selangor, MALAYSIA.

E-Mail: mohdnizal@salam.uitm.edu.my

Norli Ali

Faculty of Accountancy

Universiti Teknologi MARA

40450 Shah Alam, Selangor, MALAYSIA

E-Mail: norli170@salam.uitm.edu.my 